\title{
Nocardioides dokdonensis sp. nov., an actinomycete isolated from sand sediment
}

\begin{abstract}
Correspondence
Chi Nam Seong scnu@scnu.ac.kr
\end{abstract}

The genus Nocardioides is characterized chemotaxonomically by the combination of LL-diaminopimelic acid in the peptidoglycan and MK-8 $\left(\mathrm{H}_{4}\right)$ as the major menaquinone (O’Donnell et al., 1982; Prauser, 1976). Since the original description by Prauser (1976), the number of Nocardioides species described has increased rapidly because of improved classification resulting from the polyphasic approach. At the time of writing, there are more than 20 Nocardioides species with validly published names. Species of the genus have been isolated from various environments including soil, herbage, groundwater, an oil-shale column, black sand and beach sand, crude oil, a saline lake, a tidal flat, seawater and a water flea (Yoon et al., 2005, 2006a, b, 2007, 2008; Lee, 2007; Lee et al., 2007, 2008; Tóth et al., 2008). Of these, Nocardioides ganghwensis (Yi \& Chun, 2004a), Nocardioides aestuarii (Yi \& Chun, 2004b) and Nocardioides marinus (Choi et al., 2007) were isolated recently from tidal flat sediments.

Recently, during the course of a study on the cultivable aerobic bacterial community in sand sediment, a Grampositive bacterium that showed high levels of $16 \mathrm{~S}$ rRNA gene sequence similarity to members of the genus Nocardioides was isolated from Dokdo Island, Korea $\left(37^{\circ}\right.$

The GenBank/EMBL/DDBJ accession number for the $16 \mathrm{~S}$ rRNA gene sequence of strain FR1436 ${ }^{\top}$ is EF633986.

Biolog GP2 MicroPlate results and the fatty acid composition for strain FR $1436^{\top}$ are available as supplementary material with the online version of this paper. $\left.05^{\prime} \mathrm{N} 131^{\circ} 13^{\prime} \mathrm{E}\right)$. The sediment isolate, designated strain FR1436 ${ }^{\mathrm{T}}$, was the subject of this study.

Strain FR1436 ${ }^{\mathrm{T}}$ was isolated from a sediment sample during February 2005, using the standard dilution plating technique. Isolation was achieved using MR2A [R2A (Difco) supplemented with $3.5 \%$ artificial sea salts (Sigma)]. The isolate was routinely cultured on tryptic soy agar (TSA; Difco) at $25{ }^{\circ} \mathrm{C}$ and maintained as a glycerol suspension $(20 \%, \mathrm{w} / \mathrm{v})$ at $-80{ }^{\circ} \mathrm{C}$.

Bacterial DNA preparation, PCR amplification and sequencing of the $16 \mathrm{~S}$ rRNA gene were carried out as described previously (Chun \& Goodfellow, 1995). The resultant sequence of strain FR1436 ${ }^{\mathrm{T}}$ (1385 nt) was aligned manually against sequences obtained from the GenBank database. Phylogenetic trees were inferred from the regions available in all sequences (positions 39-1447; Escherichia coli numbering system) by using the Fitch-Margoliash (Fitch \& Margoliash, 1967) and neighbour-joining (Saitou \& Nei, 1987) methods. Evolutionary distance matrices were generated as described by Jukes \& Cantor (1969). The resultant neighbour-joining tree topology was evaluated by means of bootstrap analyses (Felsenstein, 1985) based on 1000 resamplings. Alignment and phylogenetic analyses were carried out using the jPHYDIT program (available at http://plaza.snu.ac.kr/ jchun/jphydit/) and PaUp 4.0 (Swofford, 1998), as described previously (Chun et al., 2000).

Preliminary sequence comparisons with 16S rRNA gene sequences held in GenBank indicated that strain FR1436 ${ }^{\mathrm{T}}$ 
was closely related to the genus Nocardioides. The newly determined sequence was then aligned manually against representatives of the genus Nocardioides. Strain FR $1436^{\mathrm{T}}$ showed the highest $16 \mathrm{~S}$ rRNA gene sequence similarity with respect to Nocardioides marinisabuli SBS- $12^{\mathrm{T}}(97.8 \%)$ and Nocardioides salarius CL-Z59 $9^{\mathrm{T}}(97.4 \%)$; the sequence similarities with respect to all other species of the genus Nocardioides were below $96.6 \%$. Also, strain FR1436 ${ }^{\mathrm{T}}$ occupied a distinct position in the neighbour-joining tree, clustering only with $N$. marinisabuli and $N$. salarius (Fig. 1). The tree based on the Fitch-Margoliash method showed essentially similar topology (data not shown).

In view of the results of the 16S rRNA gene sequence analysis and the subsequent phylogenetic analysis, DNADNA hybridization between FR1436 ${ }^{\mathrm{T}}$ and the type strain of $N$. marinisabuli was the only test needed to define the strain as a novel species, because the sequence similarities $(<97 \%)$ between strain FR1436 ${ }^{\mathrm{T}}$ and all Nocardioides species other than N. marinisabuli and N. salarius were below the level indicative of relatedness at the species level (Stackebrandt \& Goebel, 1994). DNA-DNA hybridization was performed using a membrane filter technique according to the method described by Baik et al. (2006). The DNA-DNA relatedness between strain FR $1436^{\mathrm{T}}$ and $N$. marinisabuli $\mathrm{KCCM} 42681^{\mathrm{T}}$ was $23.1 \pm 5.6 \%$. It is clear from the $16 \mathrm{~S}$ rRNA gene sequence and DNA-DNA hybridization data that strain FR $1436^{\mathrm{T}}$ represents a novel species in the genus Nocardioides (Wayne et al., 1987).

Bacterial growth was tested on nutrient agar (Difco), TSA, R2A agar, glucose-yeast extract agar (Gordon \& Mihm, 1962) and marine agar 2216 (Difco). Formation of mycelium and spores and production of pigment and melanin were examined for 3 weeks on several culture media, namely ISP 3, ISP 4 (Difco), ISP 5 and ISP 6 (Williams et al., 1983). The following features were determined as reported previously (Park et al., 2008): Gram stain, motility, oxidase and catalase activities, temperature, $\mathrm{pH}$ and $\mathrm{NaCl}$ tolerance for growth, acid production from sugars and hydrolysis of casein, L-tyrosine and starch. Acid-fastness was determined by means of Ziehl-Neelsen staining (Hendrickson \& Krenz, 1991). Degradation of urea $(0.15 \%, \mathrm{w} / \mathrm{v})$ and allantoin $(0.15 \%$, w/v) was tested using the medium of Gordon et al. (1974) containing $1 \% \mathrm{KH}_{2} \mathrm{PO}_{4}, 0.95 \% \mathrm{Na}_{2} \mathrm{HPO}_{4}, 0.1 \%$ yeast extract and $0.04 \%$ phenol red. Degradation of arbutin $(0.1 \%, \mathrm{w} / \mathrm{v})$ was tested using the medium of Williams et al. (1983) containing $0.3 \%$ yeast extract, $0.05 \%$ ferric ammonium citrate and $1.5 \%$ agar. Hydrolysis of Tween $20(1 \%, \mathrm{w} / \mathrm{v})$ and Tween $80(1 \%, \mathrm{w} / \mathrm{v})$ was tested using TSA as the basal medium (Barrow \& Feltham, 1993). Hydrolysis of hippurate $(1 \%$, w/v) was tested using hippurate agar (Williams et al., 1983). DNase test agar

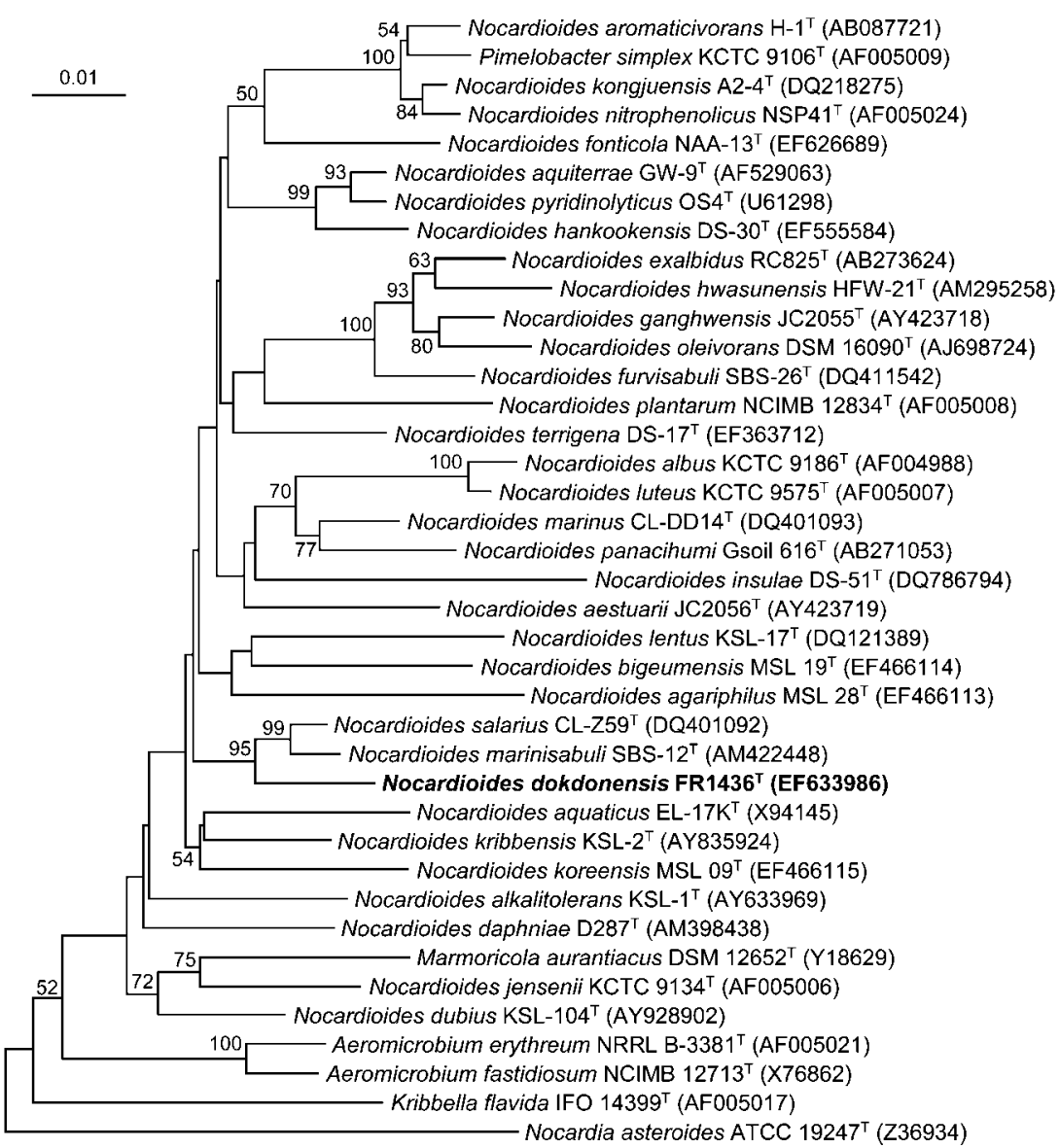

Fig. 1. Neighbour-joining phylogenetic tree, based on almost-complete 16S rRNA gene sequences, showing relationships between strain FR1436 ${ }^{\top}$ and members of the genus Nocardioides. Numbers at nodes are bootstrap percentages (based on 1000 resampled datasets). The sequence of Nocardia asteroides ATCC $19247^{\top}$ was used as an outgroup. Bar, 0.01 nucleotide substitutions per position. 
(Difco) was used to assay DNase activity. Decomposition of elastin $(0.3 \%, w / v)$, guanine $(0.3 \%, w / v)$, xanthine $(0.4 \%, \mathrm{w} / \mathrm{v})$ and xylan $(0.4 \%, \mathrm{w} / \mathrm{v})$ was checked using modified Bennett's agar as described by Gordon et al. (1974). Utilization of compounds as sole carbon sources was examined on Stevenson medium (Stevenson, 1967) suitably supplemented with each carbon source, and growth was recorded after 10 days incubation at $30{ }^{\circ} \mathrm{C}$. Utilization of compounds as sole nitrogen sources was examined on Tsukamura's medium (Tsukamura, 1975) suitably supplemented with each nitrogen source, and growth was recorded after 10 days incubation at $30{ }^{\circ} \mathrm{C}$. Other biochemical features and enzyme activities were determined using API 20NE, API $50 \mathrm{CH}$ and API ZYM kits (all from bioMérieux). Growth in the presence of various chemicals was determined on appropriately supplemented TSA after 10 days incubation at $30{ }^{\circ} \mathrm{C}$. Antibiotic resistance was determined using the disc diffusion method with

\section{Table 1. Characteristics that serve to differentiate strain $F R 1436^{\top}$ from closely related species}

Strains: 1, FR1436 ${ }^{\mathrm{T}}$; 2, N. aquaticus DSM 11439 ${ }^{\mathrm{T}}$; 3. N. kribbensis KCTC $19038^{\mathrm{T}}$; 4. N. lentus KCTC $19039^{\mathrm{T}}$; 5. N. marinisabuli KCCM 42681 ${ }^{\mathrm{T}}$; 6. N. salarius CL-Z59 ${ }^{\mathrm{T}}$. Data for reference strains are from Lawson et al. (2000), Lee et al. (2007), Kim et al. (2008) and Yoon et al. (2005, 2006a). All of the strains are positive for Gram stain, catalase, esterase lipase $(\mathrm{C} 8)^{\star}$ and leucine arylamidase ${ }^{\star}$ and negative for xanthine hydrolysis and production

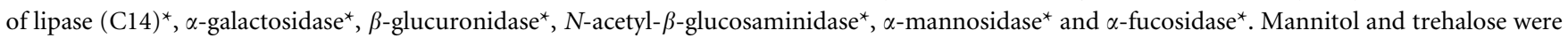
utilized by all of the strains. + , Positive; - , negative; v, variable; $\mathrm{w}$, weakly positive; ND, no data available.

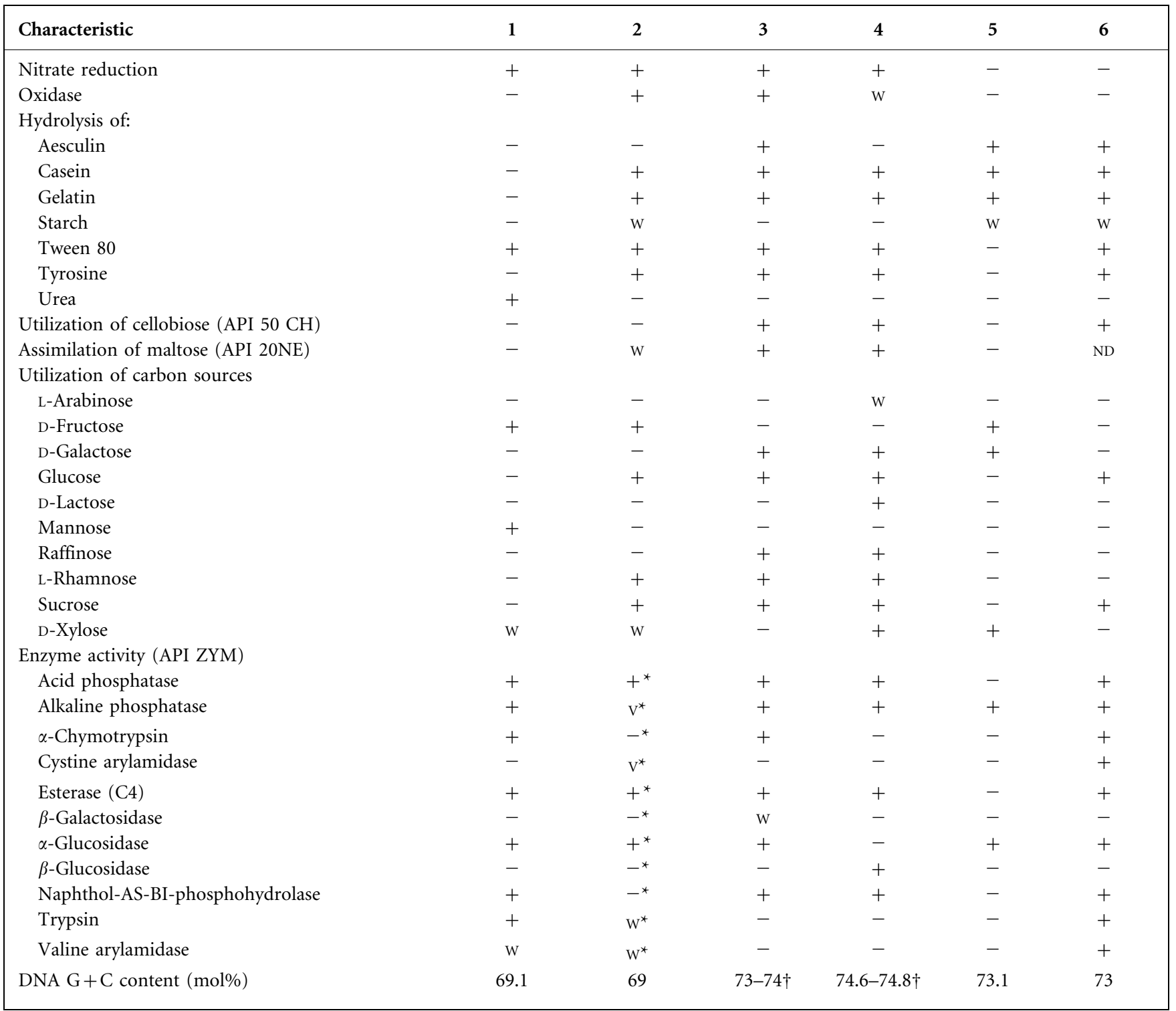

${ }^{\star}$ Data for strain N. aquaticus DSM $11439^{\mathrm{T}}$ from Yoon et al. (2006a).

$\dagger$ Ranges of values for three strains, including the type strain, in each case. 
commercial antibiotic-impregnated discs (BBL Becton Dickinson). The results were interpreted according to the guidelines set forth by the NCCLS (2003). Antibiosis against micro-organisms was checked using an overlay technique (Williams et al., 1983) on TSA and growth inhibition of target micro-organisms was measured after $24 \mathrm{~h}$ incubation at $30{ }^{\circ} \mathrm{C}$.

Cells of strain FR $1436^{\mathrm{T}}$ grown on TSA for 2 days at $25{ }^{\circ} \mathrm{C}$ were prepared and analysed for fatty acids by GLC according to the instructions of the Microbial Identification System (MIDI, 1999). The diaminopimelic acid isomer in the cell wall was determined as described by Seong et al. (1999). Isoprenoid quinones were isolated according to the method of Minnikin et al. (1984) and were analysed using HPLC as described by Collins (1985). The $\mathrm{G}+\mathrm{C}$ content of the DNA was determined using the thermal denaturation method of Marmur \& Doty (1962).

The fatty acid profile of strain FR1436 ${ }^{\mathrm{T}}$ is shown in Supplementary Table S1 (available in IJSEM Online). The predominant fatty acid was iso- $\mathrm{C}_{16: 0}(40.4 \%) ; 10$-methyl $\mathrm{C}_{17: 0}(1.4 \%)$, which is characteristic of the genus Nocardioides, was present. Considerable amounts of $\mathrm{C}_{18: 1} \omega 9 \mathrm{c}$ $(11.2 \%), \mathrm{C}_{16: 0}(7.7 \%)$ and $\mathrm{C}_{18: 0}(7.2 \%)$ were detected. The major menaquinone was MK- $8\left(\mathrm{H}_{4}\right)$, as is the case for all Nocardioides species. The DNA G $+\mathrm{C}$ content of strain FR $1436^{\mathrm{T}}$ was $69.1 \mathrm{~mol} \%$, which is similar to the value for the type strain of Nocardioides aquaticus and lower than those of the type strains of Nocardioides kribbensis, Nocardioides lentus and N. marinisabuli.

A number of phenotypic characteristics clearly distinguish strain FR1436 ${ }^{\mathrm{T}}$ from other phylogenetically related Nocardioides species (Table 1). Therefore, strain FR1436 ${ }^{\mathrm{T}}$ represents a novel species within the genus Nocardioides, for which the name Nocardioides dokdonensis sp. nov. is proposed.

\section{Description of Nocardioides dokdonensis sp. nov.}

Nocardioides dokdonensis (dok.do.nen'sis. N.L. masc. adj. dokdonensis pertaining to Dokdo, the Korean island from where the type strain was isolated).

Gram-positive and strictly aerobic bacterium. Oxidasenegative, catalase-positive and not acid-fast. Spores are not formed. Cells are non-motile short rods $(0.6-0.9 \times 1.2-$ $1.8 \mu \mathrm{m})$ in the exponential phase of growth. Substrate and aerial mycelia are not observed. Colonies on TSA are cream, circular, convex, entire, glistening and opaque. Colonies are approximately $1.0-2.0 \mathrm{~mm}$ in diameter after 3 days (on TSA at $25{ }^{\circ} \mathrm{C}$ ) and reach a maximum diameter of $3 \mathrm{~mm}$ after 7 days. Growth occurs in $0-7 \%$ (w/v) $\mathrm{NaCl}$ (optimum, 0-3\%), at pH 5-10 (optimum, pH 7) and at $4-30{ }^{\circ} \mathrm{C}$ (optimum, $25{ }^{\circ} \mathrm{C}$ ). Diffusible pigment and melanin are not produced. Acid is not produced from $0.5 \%(\mathrm{w} / \mathrm{v}) \mathrm{D}$-glucose or maltose. Does not produce $\mathrm{H}_{2} \mathrm{~S}$ or indole. Arginine dihydrolase is absent. Allantoin, guanine, Tween 20 and xylan are hydrolysed, but arbutin, DNA, elastin and hippurate are not hydrolysed. The following substrates are utilized as sole carbon and energy sources: adonitol, glycerol, melezitose, melibiose, ribose, sodium acetate, sodium citrate, sodium propionate and sodium pyruvate. Does not utilize $\mathrm{N}$-acetylglucosamine, adipate, caprate, dextran, gentiobiose, myo-inositol, DL-malate, phenyl acetate, salicin or xylitol. The following substrates are utilized as sole nitrogen sources: L-cysteine, L-hydroxyproline, L-phenylalanine, L-threonine, $\mathrm{L}$-valine and potassium nitrate. Does not utilize DL- $\alpha$-aminon-butyric acid or L-histidine. Cells are sensitive to the following antibiotics ( $\mu$ g per disc, unless otherwise indicated): amikacin (30), ampicillin (10), chloramphenicol (30), erythromycin (15), gentamicin (10), kanamycin (30), nalidixic acid (30), penicillin (10 U), polymyxin B (300 U), streptomycin (10), tetracycline (30) and vancomycin (30). The major menaquinone is MK- $8\left(\mathrm{H}_{4}\right)$. The cell-wall diamino acid is LL-diaminopimelic acid. The major fatty acids are iso$\mathrm{C}_{16: 0}, \mathrm{C}_{18: 1} \omega 9 c, \mathrm{C}_{16: 0}$ and $\mathrm{C}_{18: 0}$. The fatty acid 10-methyl $\mathrm{C}_{17: 0}$ is present, but tuberculostearic acid is absent. The DNA $\mathrm{G}+\mathrm{C}$ content of the type strain is $69.1 \mathrm{~mol} \%$. Other physiological and biochemical characteristics are given in Table 1 and Supplementary Tables S1 and S2.

The type strain, FR1436 ${ }^{\mathrm{T}}\left(=\right.$ KCTC $\left.19309^{\mathrm{T}}=\mathrm{JCM} 14815^{\mathrm{T}}\right)$, was isolated from sand sediment from a beach on Dokdo Island, Republic of Korea.

\section{Acknowledgements}

This work was supported by the BK21 programme (Ministry of Education and Human Resources Development), Republic of Korea.

\section{References}

Baik, K. S., Park, Y.-D., Seong, C. N., Kim, E. M., Bae, K. S. \& Chun, J. (2006). Glaciecola nitratireducens sp. nov. isolated from seawater. Int $J$ Syst Evol Microbiol 56, 2185-2188.

Barrow, G. I. \& Feltham, R. K. A. (1993). Cowan and Steel's Manual for the Identification of Medical Bacteria, 3rd edn. Cambridge: Cambridge University Press.

Choi, D. H., Kim, H. M., Noh, J.-H. \& Cho, B. C. (2007). Nocardioides marinus sp. nov. Int J Syst Evol Microbiol 57, 775-779.

Chun, J. \& Goodfellow, M. (1995). A phylogenetic analysis of the genus Nocardia with $16 \mathrm{~S}$ rRNA gene sequences. Int J Syst Bacteriol 45, 240-245.

Chun, J., Bae, K. S., Moon, E. Y., Jung, S. O., Lee, H. K. \& Kim, S. J. (2000). Nocardiopsis kunsanensis sp. nov., a moderately halophilic actinomycete isolated from a saltern. Int J Syst Evol Microbiol 50, 1909-1913.

Collins, M. D. (1985). Analysis of isoprenoid quinones. Methods Microbiol 18, 329-366.

Felsenstein, J. (1985). Confidence limits on phylogenies: an approach using the bootstrap. Evolution 39, 783-791.

Fitch, W. M. \& Margoliash, E. (1967). Construction of phylogenetic trees: a method based on mutation distances as estimated from cytochrome $c$ sequences is of general applicability. Science 155, 279-284.

Gordon, R. E. \& Minm, J. M. (1962). Identification of Nocardia caviae (Erikson) nov. comb. Ann N Y Acad Sci 98, 628-636.

Gordon, R. E., Barnett, D. A., Handerhan, J. E. \& Pang, C. H.-N. (1974). Nocardia coeliaca, Nocardia autotrophica, and the nocardin strain. Int J Syst Bacteriol 24, 54-63. 
Hendrickson, D. A. \& Krenz, M. M. (1991). Reagents and stains. In Manual of Clinical Microbiology, pp. 1289-1314. Edited by A. Balows, W. J. Hausler, Jr, K. L. Herrmann, H. D. Isenberg \& H. J. Shadomy. Washington, DC: American Society for Microbiology.

Jukes, T. H. \& Cantor, C. R. (1969). Evolution of protein molecules. In Mammalian Protein Metabolism, vol. 3, pp. 21-132. Edited by H. N. Munro. New York: Academic Press.

Kim, H. M., Choi, D. H., Hwang, C. Y. \& Cho, B. C. (2008). Nocardioides salarius sp. nov., isolated from seawater enriched with zooplankton. Int J Syst Evol Microbiol 58, 2056-2064.

Lawson, P. A., Collins, M. D., Schumann, P., Tindall, B. J., Hirsch, P. \& Labrenz, M. (2000). New LL-diaminopimelic acid-containing actinomycetes from hypersaline, heliothermal and meromictic Antarctic Ekho Lake: Nocardioides aquaticus sp. nov. and Friedmanniella lacustris sp. nov. Syst Appl Microbiol 23, 219-229.

Lee, S. D. (2007). Nocardioides furvisabuli sp. nov., isolated from black sand. Int J Syst Evol Microbiol 57, 35-39.

Lee, D. W., Hyun, C.-G. \& Lee, S. D. (2007). Nocardioides marinisabuli sp. nov., a novel actinobacterium isolated from beach sand. Int J Syst Evol Microbiol 57, 2960-2963.

Lee, S. D., Lee, D. W. \& Kim, J. S. (2008). Nocardioides hwasunensis sp. nov. Int J Syst Evol Microbiol 58, 278-281.

Marmur, J. \& Doty, P. (1962). Determination of the base composition of deoxyribonucleic acid from its thermal denaturation temperature. $J$ Mol Biol 5, 109-118.

MIDI (1999). Sherlock Microbial Identification System Operating Manual, version 3.0. Newark, DE: MIDI, Inc.

Minnikin, D. E., O’Donnell, A. G., Goodfellow, M., Alderson, G., Athayle, M., Schaal, A. \& Parlett, J. H. (1984). An integrated procedure for the extraction of bacterial isoprenoid quinones and polar lipids. J Microbiol Methods 2, 233-241.

NCCLS (2003). Performance Standards for Antimicrobial Disk Susceptibility Tests, 8th edn. Approved Standard, M2-A8. Wayne, PA: National Committee for Clinical Laboratory Standards.

O’Donnell, A. G., Goodfellow, M. \& Minnikin, D. E. (1982). Lipids in the classification of Nocardioides: reclassification of Arthrobacter simplex (Jensen) Lochhead in the genus Nocardioides (Prauser) emend. O'Donnell et al. as Nocardioides simplex comb. nov. Arch Microbiol 133, 323-329.

Park, S. C., Kim, M. S., Baik, K. S., Kim, E. M., Rhee, M. S. \& Seong, C. N. (2008). Chryseobacterium aquifrigidense sp. nov., isolated from a water-cooling system. Int J Syst Evol Microbiol 58, 607-611.

Prauser, H. (1976). Nocardioides, a new genus of the order Actinomycetales. Int J Syst Bacteriol 26, 58-65.
Saitou, N. \& Nei, M. (1987). The neighbor-joining method: a new method for reconstructing phylogenetic trees. Mol Biol Evol 4, 406-425.

Seong, C. N., Kim, Y. S., Baik, K. S., Lee, S. D., Hah, Y. C., Kim, S. B. \& Goodfellow, M. (1999). Mycolic acid-containing actinomycetes associated with activated sludge foam. J Microbiol 37, 66-72.

Stackebrandt, E. \& Goebel, B. M. (1994). Taxonomic note: a place for DNA-DNA reassociation and $16 \mathrm{~S}$ rRNA sequence analysis in the present species definition in bacteriology. Int J Syst Bacteriol 44, 846-849.

Stevenson, I. L. (1967). Utilisation of aromatic hydrocarbons by Arthrobacter spp. Can J Microbiol 13, 205-212.

Swofford, D. L. (1998). Phylogenetic analysis using parsimony (PAUP). Version 4. Sunderland, MA: Sinauer Associates.

Tóth, E. M., Kéki, Z., Homonnay, Z. G., Borsodi, A. K., Márialigeti, K. \& Schumann, P. (2008). Nocardioides daphniae sp. nov., isolated from Daphnia cucullata (Crustacea: Cladocera). Int J Syst Evol Microbiol 58, 78-83.

Tsukamura, M. (1975). Numerical analysis of the relationship between Mycobacterium, Rhodochrous group, and Nocardia by use of hypothetical median organisms. Int J Syst Bacteriol 25, 329-355.

Wayne, L. G., Brenner, D. J., Colwell, R. R., Grimont, P. A. D., Kandler, O., Krichevsky, M. I., Moore, L. H., Moore, W. E. C., Murray, R. G. E. \& other authors (1987). International Committee on Systematic Bacteriology. Report of the ad hoc committee on reconciliation of approaches to bacterial systematics. Int J Syst Bacteriol 37, 463-464.

Williams, S. T., Goodfellow, M., Alderson, G., Wellington, E. M. H., Sneath, P. H. A. \& Sackin, M. J. (1983). Numerical classification of Streptomyces and related genera. J Gen Microbiol 129, 1743-1813.

Yi, H. \& Chun, J. (2004a). Nocardioides ganghwensis sp. nov., isolated from tidal flat sediment. Int J Syst Evol Microbiol 54, 1295-1299.

Yi, H. \& Chun, J. (2004b). Nocardioides aestuarii sp. nov., isolated from tidal flat sediment. Int J Syst Evol Microbiol 54, 2151-2154.

Yoon, J.-H., Kim, I.-G., Lee, M.-H. \& Oh, T.-K. (2005). Nocardioides kribbensis sp. nov., isolated from an alkaline soil. Int J Syst Evol Microbiol 55, 1611-1614.

Yoon, J.-H., Lee, C.-H. \& Oh, T.-K. (2006a). Nocardioides lentus sp. nov., isolated from an alkaline soil. Int J Syst Evol Microbiol 56, 271-275.

Yoon, J.-H., Lee, J.-K., Jung, S.-Y., Kim, J.-A., Kim, H.-K. \& Oh, T.-K. (2006b). Nocardioides kongjuensis sp. nov., an $N$-acylhomoserine lactone-degrading bacterium. Int J Syst Evol Microbiol 56, 1783-1787.

Yoon, J.-H., Kang, S.-J., Lee, C.-H. \& Oh, T.-K. (2007). Nocardioides insulae sp. nov., isolated from soil. Int J Syst Evol Microbiol 57, 136-140.

Yoon, J.-H., Kang, S.-J., Lee, M.-H. \& Oh, T.-K. (2008). Nocardioides hankookensis sp. nov., isolated from soil. Int J Syst Evol Microbiol 58, 434-437. 